\title{
Coral reef fish assemblages at Clipperton Atoll (Eastern Tropical Pacific) and their relationship with coral cover
}

\author{
Aurora M. Ricart ${ }^{1}$, Fabián A. Rodríguez-Zaragoza ${ }^{2}$, Carlos González-Salas ${ }^{3}$, Marco Ortiz ${ }^{4}$, \\ Amílcar L. Cupul-Magaña ${ }^{5}$, Mehdi Adjeroud ${ }^{6}$

\begin{abstract}
${ }^{1}$ Departament d'Ecologia, Facultat de Biologia, Universitat de Barcelona. Av. Diagonal 643, 08028 Barcelona, Spain. ${ }^{2}$ Departamento de Ecología, CUCBA. Universidad de Guadalajara. Camino Ramón Padilla Sánchez No. 2100 Nextipac, Zap., Jal., C.P. 45110, México. E-mail: rzf39259@ cucba.udg.mx

${ }^{3}$ Campus de Ciencias Biológicas y Agropecuarias, Universidad Autónoma de Yucatán. Carr. Mérida-Xmatkuil Km. 15.5 A.P. 4-116 Itzimná P.O. Box 97100, Yuc., México.

${ }^{4}$ Instituto Antofagasta, Universidad de Antofagasta, P.O. Box 170, Antofagasta, Chile. Ixtapa, 48280 Pto. Vallarta, Jal., México.

${ }^{6}$ Institut de Recherche pour le Développement (IRD), UMR 9220 ENTROPIE \& Laboratoire d'Excellence CORAIL
\end{abstract} \\ ${ }^{5}$ Departamento de Ciencias Biológicas, CUCosta, Universidad de Guadalajara, Av. Universidad de Guadalajara 203 , Del. \\ UPVD, 52 avenue Paul Alduy 66860 Perpignan, France.
}

\begin{abstract}
Summary: Clipperton Atoll, one of the most isolated coral reefs worldwide, is of great scientific interest due to its geomorphology and high levels of endemism. This study explored the reef fish assemblage structure of Clipperton Atoll and its relationship with live coral cover. Nine stations were sampled at three sites and three depths $(6,12$ and $20 \mathrm{~m})$ around the reef, measuring fish species richness and biomass and hermatypic coral cover (at genus level). We evaluated variation in species richness, biomass and diversity of fish assemblages among sites and depths, as well as the relationship between the entire fish assemblage composition and live coral cover. The results showed that species richness and biomass were similar among sites, but differed across depths, increasing with depth. In contrast, diversity differed among sites but not among depths. Multivariate analyses indicated that fish assemblage composition differed among sites and depths in relation to changes in cover of coral of the genera Pocillopora, Porites, Pavona and Leptoseris, which dominate at different depths. The results showed that fish species richness and diversity were low at Clipperton Atoll and that, in isolated coral reefs with a low habitat heterogeneity and low human disturbance, live coral cover has a significant influence on the spatial variation of the reef fish assemblages. This study highlights the importance of coral habitat structure in shaping coral reef fish assemblages.
\end{abstract}

Keywords: species-habitat interaction; reef fish diversity; spatial variation; habitat structure.

Comunidades de peces del atolón de Clipperton (Pacífico oriental tropical) y su relación con la cobertura de corales

Resumen: El atolón de Clipperton, uno de los arrecifes de coral más aislados del mundo, presenta un gran interés científico por su geomorfología y endemismo. Este estudio analizó la estructura de las comunidades de peces de arrecife de este atolón y su relación con la cobertura de coral vivo. Para ello se muestrearon nueve estaciones alrededor del arrecife en tres sitios a tres profundidades $(6,12,20 \mathrm{~m})$, registrando, la riqueza y biomasa de peces, así como la cobertura de coral hermatípico a nivel de género. Se evaluó la variación de la riqueza, biomasa y diversidad de peces entre sitios y profundidades, así como la relación de la composición y biomasa de peces con la cobertura de coral vivo. Los resultados mostraron que la riqueza y biomasa fueron similares entre los sitios, pero diferentes entre profundidades, ya que incrementan con la profundidad. En contraste, la diversidad difirió entre sitios pero no entre profundidades. Los análisis multidimensionales indicaron que la comunidad de peces fue diferente entre sitios y profundidades, relacionándolo con la cobertura de coral de los géneros Pocillopora, Porites, Pavona y Leptoseris, que dominan a distinta profundidad. Los resultados evidenciaron una baja riqueza y diversidad de peces arrecifales en el atolón de Clipperton. En arrecifes de coral aislados, con baja heterogeneidad de hábitats y poca perturbación humana, la cobertura de coral vivo influye en la variación espacial de las comunidades de peces arrecifales. Este estudio resalta la importancia de la estructura del hábitat de coral en la conformación de las comunidades de peces arrecifales.

Palabras clave: interacción especies-hábitat; diversidad de peces de arrecife; variación espacial; estructura del hábitat.

Citation/Como citar este artículo: Ricart A.M., Rodríguez-Zaragoza F.A., González-Salas C., Ortiz M., Cupul-Magaña A.L., Adjeroud M. 2016. Coral reef fish assemblages at Clipperton Atoll (Eastern Tropical Pacific) and their relationship with coral cover. Sci. Mar. 80(4): 479-486. doi: http://dx.doi.org/10.3989/scimar.04301.12B

Editor: A. García-Rubies.

Received: June 23, 2015. Accepted: July 6, 2016. Published: October 17, 2016.

Copyright: (C) 2016 CSIC. This is an open-access article distributed under the terms of the Creative Commons Attribution (CC-by) Spain 3.0 License. 


\section{INTRODUCTION}

Coral reefs are extremely complex systems, with high intra and inter-habitat heterogeneity generating multiple ecological niches for a great number of species (Jackson et al. 2001). The high structural complexity of coral reefs provides shelter and food to a variety of species of different taxonomic groups (Anderson et al. 1981, Sale 1991, Ohman and Rajasuriya 1998, Chittaro 2004). Fish assemblages are one of the most important biological components within the coral reef ecosystem, since they constitute its most conspicuous motile component and tend to demonstrate specific associations with reef structures (Arias-González et al. 2006, Méndez et al. 2006). Fishes, as main consumers, exert a top-down control over the food webs within coral reefs and also play a key role in maintaining ecosystem resilience (Arias-González et al. 2006, Aguilar-Medrano and Calderón-Aguilera 2015, Cáceres et al. 2015).

Coral reef fish assemblage structure patterns have been studied widely in relation to numerous biological and physical parameters of the reef environment (e.g. Galzin 1987, Ault and Johnson 1998, DominiciArosemena and Wolff 2006, Arias-González et al. 2008). There are many studies linking patterns of the reef fish assemblage structure (i.e. species richness, abundance, diversity and composition) with particular attributes of the coral reef habitat such as coral species richness, composition and morphological diversity (i.e. reef geomorphology, number of holes or availability of shelter, rugosity-flattening and depth) (e.g. Rodríguez-Zaragoza et al. 2011, Alvarez-Filip et al. 2011, Rodríguez-Zaragoza and Arias-González 2015). In particular, some authors consider that a strong relationship exists between fish fauna and corals in terms of live coral cover (LCC), such that increased variation in coral species can support high abundance and richness in fish assemblages (Adjeroud et al. 1998. Arias-González et al. 2008, 2011, Acosta-González et al. 2013). However, this relationship has not been found in other studies (Roberts and Ormond 1987, Dominici-Arosemena and Wolff 2006). This discrepancy can be attributed to the different geomorphological features (i.e. high topographic complexity) and landscape patterns (e.g. presence of other habitats) in each study area, as well as the particular study methodologies and scales (Chabanet et al. 1997, Mellin et al. 2008). On the other hand, depth is an important factor determining coral species distribution. This zonation has been attributed to a combination of physical and biological factors affecting coral, including predation by fish, wave exposure and differential use of light by specific symbiotic dinoflagellates of coral species that control the abundance and distribution of hermatypic corals (Iglesias-Prieto et al. 2004). These two variables, LCC and depth, are not independent of each other, but the extent to which they can predict general patterns of reef fish assemblage structure remains unclear and has been poorly studied in isolated coral reefs systems with low human impact, such as Clipperton Atoll.
Clipperton Atoll is located on the western boundary of the Eastern Tropical Pacific (ETP) on the route of the North Equatorial Current and, intermittently, on the North Equatorial Counter Current. The isolation of the Clipperton Atoll has created difficulties for scientific exploration (Fourriére et al. 2014), but a few significant studies of the coral (Glyn et al. 1996, Carricart-Gavinet and Reyes-Bonilla 1999) and fish species (Allen and Robertson 1997, Robertson and Allen 1996, Fourriére et al. 2014) have shown that Clipperton is of great interest because of its biogeographical importance and high degree of endemism (Glynn et al. 1996, Veron et al. 2015). Despite the small size of the atoll, Clipperton is one of the richest areas of endemism in the world, with 1.5 endemic species per square kilometre (Allen 2007). Its high degree of endemism represents $7 \%$ of the reef species (Béarez and Seret 2008, Fourriére et al. 2014). Clipperton has a unique reef ecosystem in which the coral reefs constitute the major structural components of the landscape, since no rocky, seagrass or mangrove habitats are present (Glynn et al. 1996). Another special feature of this reef is its "optimal" condition of reef health, since it has a high percentage of LCC with no direct human impacts, natural degradation from hurricanes, coral bleaching or Acanthaster planci outbreaks in recent decades (Salvat et al. 2008). These special features, in addition to those mentioned above, allow us to assess the direct relationship between fish assemblage structure and the coverage and distribution of corals across different depths. In this study, we evaluate the reef fish assemblage structure of Clipperton Atoll and its relationship with LCC. We hypothesize that LCC will influence the structure of the reef fish assemblages, with a positive relationship occurring between LCC and species richness, biomass, diversity and composition of reef fish assemblages.

\section{MATERIALS AND METHODS}

\section{Study area}

Clipperton Atoll (France) is located $\sim 1200 \mathrm{~km}$ southwest coast of Mexico, $\sim 945 \mathrm{~km}$ south of the Revillagigedo Archipelago, $2400 \mathrm{~km}$ northwest of the Galapagos Islands and $\sim 5700 \mathrm{~km}$ from the Line Islands (Fig. 1). Comprising a total area of $12 \mathrm{~km}^{2}$, the atoll is $4 \mathrm{~km}$ across at its widest. The emergent surface consists of a narrow ring of land (from 40 to $400 \mathrm{~m}$ wide) around a central lagoon of $10 \mathrm{~km}^{2}$, which is isolated from the ocean. Unlike coral reefs on the continental shelf in the ETP, the highly isolated Clipperton Atoll is not affected by the drainage of permanent rivers, coastal lagoons, mangroves and extensive sandy shores (Glynn and Wellington 1983). The water is therefore less turbid, allowing light penetration and promoting the growth of hermatypic coral to a depth of $70 \mathrm{~m}$ (Glynn et al. 1996). The full geomorphological and oceanographic characteristics of this reef have been described by Glynn et al. (1996), Allen and Robertson (1997) and Robertson and Allen (1996). 


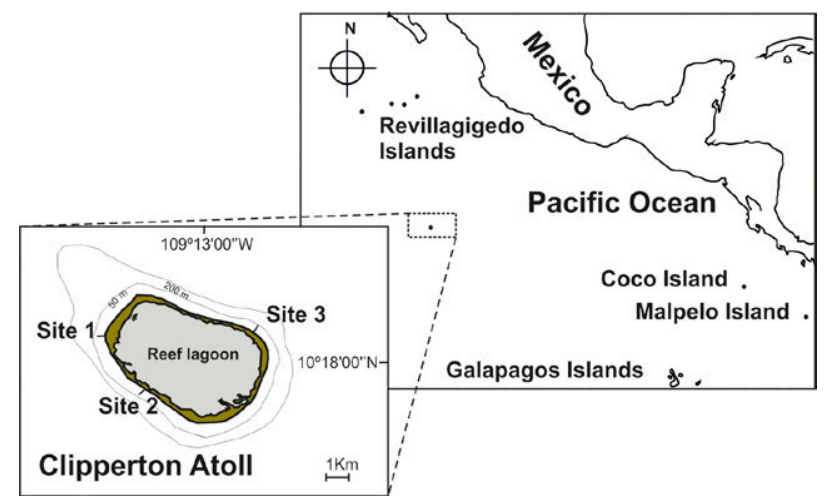

Fig. 1. - Location of study area and sampling sites at the Clipperton Atoll.

\section{Data collection}

Sampling was conducted in March 2005. A total of nine stations were sampled, at three sites (A, B and C) and three depths $(6,12$ and $20 \mathrm{~m})$ on the outer reef slope around the atoll (Fig. 1). Sites were selected as a function of their geomorphology and relative live coral abundance. At each station, three transects were sampled. For each transect, a visual census $(2 \times 25 \mathrm{~m})$ was performed in order to record fish species richness, abundance (number of individuals) and size. Fish were classified into 13 sizes at intervals of $5 \mathrm{~cm}$, from $5 \mathrm{~cm}$ to $>100 \mathrm{~cm}$. The biomass of each species was estimated as fish size and abundance, using the formula $B=a L^{b}$, where $B$ is biomass $\left(\mathrm{g} \mathrm{m}^{-2}\right), L$ is the weighted average height, and $a$ and $b$ are constants for the length-weight relationship. The constants $a$ and $b$ were obtained from Fishbase (Froese and Pauly 2015). When no constants were available for a species, the constant of a species of the same genus and similar size and morphology was used. In addition, corrections to the length-to-height ratio for certain constants were estimated from furcal or standard length, in order to standardize the total length. The biomass of each individual was then multiplied by the total abundance of individuals and divided by the area of the sampled transect $\left(50 \mathrm{~m}^{2}\right)$. For each fish visual census, the hermatypic coral cover was recorded at the genus level (Porites, Pavona, Pocillopora and Leptoseris) at $25 \mathrm{~cm}$ intercepts along a $25 \mathrm{~m}$ long transect. The percentage of cover was estimated as the total number of records for a coral genus at the intercepts, divided by the total number of intercepts per transect and multiplied by 100 .

\section{Data analysis}

Sampling effort was assessed using observed and estimated species accumulation curves generated with the Chao 1, Chao 2 and Jackknife 2 estimators, as well as cumulative Shannon diversity index ( $\mathrm{H}^{\prime}$, nats) diversity. Jackknife 2 and Chao 2 predict the number of unique and duplicated species that remain to be sampled. The Chao 1 estimator considers the number of singletons and doubletons among samples. The curves were constructed with 10000 randomizations without replacement, using EstimateS V9.1 (Colwell 2013). For each site and depth, total fish species richness (S) was also analysed using individual-based rarefaction curves (Colwell 2013). Fish diversity was examined based on the biomass of the species and estimation of the Shannon diversity $\left(\mathrm{H}^{\prime}\right)$ and Pielou evenness $\left(\mathrm{J}^{\prime}\right)$.

A two-way ANOVA, with site (3 levels: A, B, C) and depth (3 levels: 6, 12, $20 \mathrm{~m}$ ) as fixed factors, was used to compare species richness, total biomass $\left(\mathrm{g} \mathrm{m}^{-2}\right)$, Shannon diversity, Pielou evenness, and total (LCC) and coral genus cover. Where a significant difference was found $(p \leq 0.05)$, a post hoc Tukey HSD test was used to distinguish among groups. Where necessary, data were $\log _{10}$-transformed in order to comply with the requirements of homogeneity of variance and normality. Non-transformed values (means \pm SE) are shown in the figures and tables.

A permutational multivariate analysis of variance (PERMANOVA) was performed in order to assess the variation in the composition of fish assemblages, using 9999 permutations and a Bray-Curtis similarity matrix generated with the biomass of each species ( $g$ $\mathrm{m}^{-2}$ ), following fourth-root transformation. The PERMANOVA was based on the previous ANOVA design. Significant terms and interactions were evaluated with Pseudo- $t$ statistic pairwise comparisons. Differences in multivariate dispersion were tested by PERMDISP analysis on the same matrix. A two-way similarity percentage (SIMPER) analysis was used to identify which species primarily accounted for the observed differences. These analyses were made in PRIMER V6.1+ PERMANOVA (Clarke and Gorley 2006, Anderson et al. 2008).

Canonical redundancy analysis (RDA) was used to assess the direct linear relationship between the fish assemblages and coral cover and depth. Fish biomass values were transformed using Hellinger pre-treatment (Legendre and Gallagher 2001), and a forward selection was utilized to find the best set of explanatory variables. The Trace statistic was employed to assess model fit. Significant species vectors were overlaid on the RDA ordination to examine how fish species were related to levels of coral genus cover and depths. Species vectors represent raw Pearson correlation calculated for each species with the original RDA axes. Only species found to be important for each site and depth in the SIMPER analyses were represented. Statistical significance was tested with 9999 permutations in CANOCO 4.5 (ter Braak and Šmilauer 2002).

\section{RESULTS}

\section{Fish assemblages}

In total, 45 fish species were found, representing 35 genera and 22 families. The most common families were Labridae (7 species), Acanthuridae (5), Carangidae (3), Kyphosidae (3), Muraenidae (3) and Serranidae (3). The average fish biomass for Clipperton Atoll was $356.6 \mathrm{~g} \mathrm{~m}^{-2}$. Fish species, and their biomass and abundance, are detailed in the Supplementary Material, Table S1. Species accumulation curves showed 
Table 1. - Statistical results of two-way ANOVA for species richness, biomass, diversity indexes and coral cover (i.e. total live coral cover, Pocillopora, Porites and Pavona) among sites and depths at Clipperton Atoll. The outcomes of the PERMANOVA and PERMDISP are presented, which compare the species composition of fish assemblages among sites across depths.

\begin{tabular}{|c|c|c|c|c|c|}
\hline Source & $\mathrm{F}$ & P-value & Source & $\mathrm{F}$ & P-value \\
\hline Average species richness & & & Total biomass & & \\
\hline Site & 1.42 & 0.271 & Site & 1.73 & 0.209 \\
\hline Depth & 8.81 & 0.003 & Depth & 4.18 & 0.035 \\
\hline Sitexdepth & 2.45 & 0.089 & Sitexdepth & 0.83 & 0.527 \\
\hline Shannon diversity ( $\left.\mathrm{H}^{\prime}\right)$ & & & Pielou evenness (J') & & \\
\hline Site & 7.41 & 0.005 & Site & 6.47 & 0.009 \\
\hline Depth & 0.78 & 0.473 & Depth & 1.58 & 0.237 \\
\hline Sitexdepth & 1.81 & 0.176 & Sitexdepth & 0.84 & 0.521 \\
\hline Fish composition & Pseudo-F & P-value & PERMDISP (P-value) & & \\
\hline Site & 2.4006 & 0.0023 & 0.3227 & & \\
\hline Depth & 5.1781 & 0.0001 & 0.2997 & & \\
\hline Sitexdepth & 1.9268 & 0.0033 & 0.0791 & & \\
\hline Source & $\mathrm{F}$ & $\mathrm{P}$-value & Source & $\mathrm{F}$ & P-value \\
\hline Porites cover & & & Pavona cover & & \\
\hline Site & 18.70 & $<0.001$ & Site & 24.37 & $<0.001$ \\
\hline Depth & 82.09 & $<0.001$ & Depth & 6.21 & $\mathbf{0 . 0 1 0}$ \\
\hline Sitexdepth & 50.64 & $<0.001$ & Sitexdepth & 7.26 & 0.002 \\
\hline Pocillopora cover & & & Live coral cover (LCC) & & \\
\hline Site & 23.54 & $<0.001$ & Site & 25.60 & $<0.001$ \\
\hline Depth & 97.80 & $<0.001$ & Depth & 44.59 & $<0.001$ \\
\hline Sitexdepth & 8.04 & $<0.001$ & Sitexdepth & 49.13 & $<0.001$ \\
\hline
\end{tabular}

that sampling effort was representative, with between $60 \%$ and $73 \%$ of the expected species inventory, suggesting that 30 unique species and 16 duplicate species remained to be sampled. However, singleton and doubleton species were accurately recorded. Likewise, the Shannon diversity curve showed asymptotic behaviour, indicating that the sampling effort recorded the main species that form the fish assemblage structure (Supplementary Material, Fig. S1 A-B).

Individual-based rarefactions confirmed that site $\mathrm{C}$ had the highest total species richness ( 39 species) but a low number of individuals. Site A showed fewer species (34) but the highest fish abundance. In contrast, site B had the lowest species richness (31) and abundance. Rarefactions among depths also showed that depths 12 and $20 \mathrm{~m}$ showed the highest total species richness (39 and 33 species, respectively) and abundance, while the shallower depth $(6 \mathrm{~m})$ had few species (24) and the lowest number of individuals (Supplementary Material, Fig. S1 C-D).

Our results confirmed that average fish species richness and total biomass were similar among sites but differed among depths, showing higher values at deeper stations (Table 1, Fig. 2A-D). Shannon diversity $\left(\mathrm{H}^{\prime}\right)$ and Pielou evenness $\left(\mathrm{J}^{\prime}\right)$ differed significantly among sites, but did not vary among depths (Table 1, Fig. 2E-H). Under both indexes, the highest values were found at site $\mathrm{B}$ and the lowest at site $\mathrm{C}$.

The composition of reef fish assemblages differed among sites and depths (Table 1). The fish assemblage at site $\mathrm{A}$ was different from that at sites $\mathrm{B}$ and $\mathrm{C}$, and the fish composition varied significantly at all depths. The PERMDISP test showed that both factors (site and depth) and their interaction have a location dispersion effect, suggesting that the multivariate dispersion within groups was homogeneous and that each factor favoured the establishment of different reef fish assemblages (Table 1).

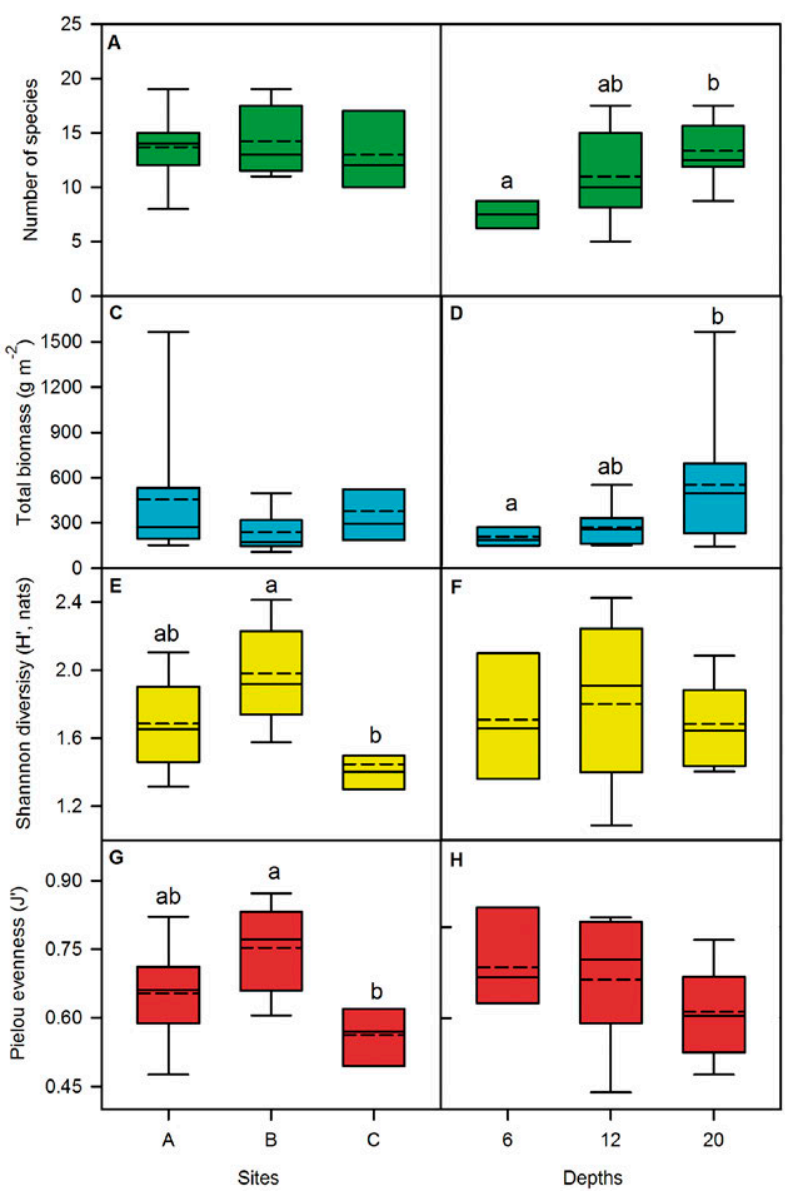

Fig. 2. - Structure of reef fish assemblages at three sites and three depths at Clipperton Atoll. Species richness per site (A) and depth (B); total biomass per site (C) and depth (D). Shannon diversity $\left(\mathrm{H}^{\prime}\right)$ per site $(\mathrm{E})$ and depth $(\mathrm{F})$; Pielou evenness $\left(\mathrm{J}^{\prime}\right)$ per site $(\mathrm{G})$ and depth $(\mathrm{H})$. In the box and whisker plots, means are dotted lines, 50th percentiles (medians) are solid lines, and boxes correspond to the 25th and 75 th percentiles. Error bars mark the 5th and 95th percentiles.

The lowercase letters correspond to the Tukey HSD test results. 


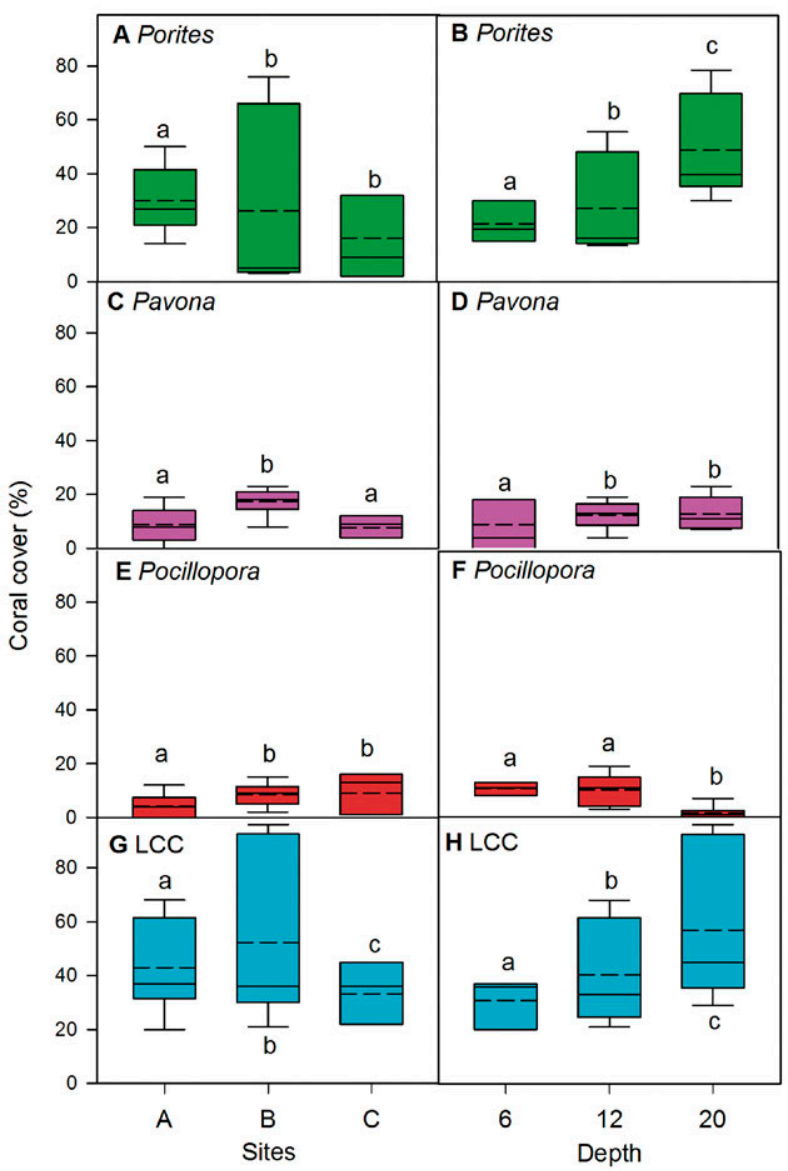

Fig. 3. - Hermatypic coral cover at Clipperton Atoll. Porites cover by site (A) and depth (B). Pavona cover by site (C) and depth (D). Pocillopora cover by site $(\mathrm{E})$ and depth $(\mathrm{F})$. Total live coral cover (LCC) by site $(\mathrm{G})$ and depth $(\mathrm{H})$. In the box and whisker plots, means are dotted lines, 50th percentiles (medians) are solid lines, and boxes correspond to the 25th and 75th percentiles. Error bars mark the 5th and 95th percentiles. The lowercase letters correspond to the Tukey HSD test results.

The main species responsible for the dissimilarity in the composition of reef fish assemblages between site A and sites B and C were Epinephelus labriformis, Caranx lugubris, Dermatolepis dermatolepis, Ctenochaetus marginatus, Caranx melampygus, Melichthys niger, Sufflamen verres, Bodianus diplotaenia, Aulostomus chinensis, Kyphosus elegans, Scarus rubroviolaceus and Paranthias colonus (Supplementary Material, Table S2). The species that contributed most to dissimilarity among depths were Myripristis berndti, M. niger, $S$. rubroviolaceus, $P$. colonus, $C$. melampygus, $D$. dermatolepis, C. lugubris, C. marginatus, Acanthurus triostegus, $S$. verres, Acanthurus nigricans, K. elegans, E. labriformis and Kyphosus analogus (Supplementary Material, Table S3).

\section{Coral cover}

In general, the Porites corals were the most abundant among sites and depths, followed by Pavona and Pocillopora, with lower coverage values (Fig. 3A-F). In turn, Leptoseris corals were only found at site B, with $0.2 \%$ cover at depth $20 \mathrm{~m}$. Coverage values of Porites, Pavona and Pocillopora, as well as LCC, dif- fered significantly among sites and depths (Table 1). Porites cover was higher at site A and lower at sites B and $\mathrm{C}$. It was also higher at deeper stations, particularly at $20 \mathrm{~m}$ (Fig. 3A, B). Meanwhile, the Pavona corals had the highest cover at site $\mathrm{B}$ and the lowest at 12 and $20 \mathrm{~m}$ depth (Fig. 3C, D). The cover of Pocillopora was higher at sites B and $\mathrm{C}$ and also decreased with depth, showing its highest coverage at the shallow depths (6 and $12 \mathrm{~m}$ ) (Fig. 3E, F). The LCC showed its highest value at site $\mathrm{B}$, with sites $\mathrm{A}$ and $\mathrm{C}$ both showing lower values. Moreover, LCC was higher at deeper stations, particularly at $20 \mathrm{~m}$ depth, where the values were twice as high as those found at $6 \mathrm{~m}$ (Fig. 3G, H).

\section{Fish assemblages in relation to coral cover and depth}

RDA outcomes showed that the variation of the reef fish assemblage composition was mainly related to the cover of the coral genera Pocillopora, Porites and Pavona as well as depth. (Fig. 4). Canonical axis 1 separated the transects by depth and cover of Pocillopora, Porites and Leptoseris, while canonical axis 2 separated the transects based on the Pavona cover. The first axis represented a depth gradient, with a clear zonation of the coverage of coral genera. The second axis separated site A from sites B and C. Depth and cover of Porites and Leptoseris were positively correlated with the presence of the fish species $M$. berndti, K. elegans, P. colonus and D. dermatolepis at

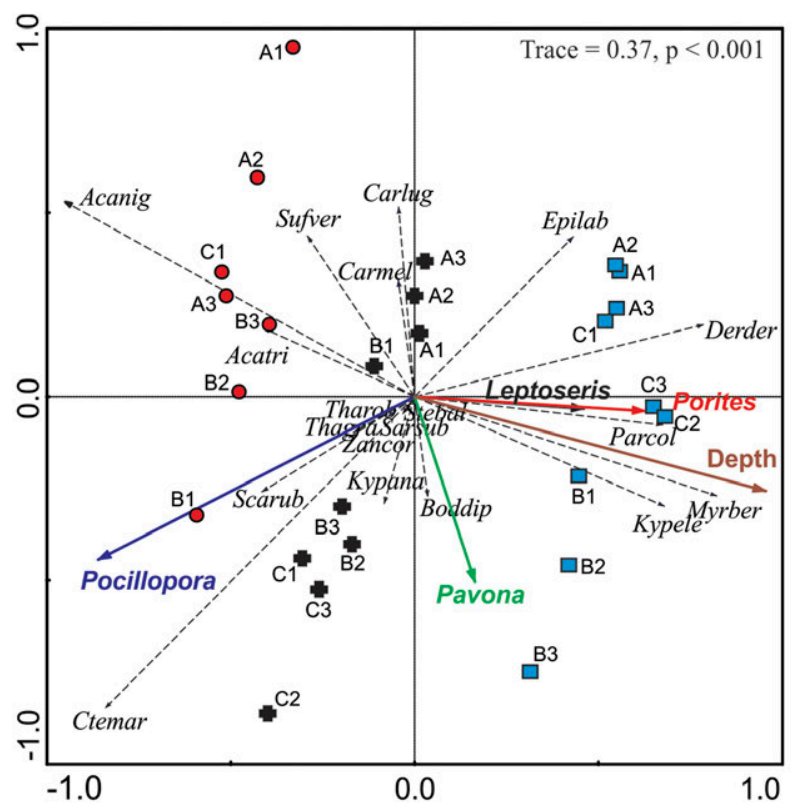

Fig. 4. - Redundancy analysis triplot and relationships among fish biomass per species, environmental variables, and transects at Clipperton Atoll. The scientific names correspond to the first three letters of genus and species. Fish species are represented by arrows with thin and segmented lines. Only those species with the greatest contribution to the SIMPER analysis are shown. Environmental variables (depth and coral cover) are thick solid arrows. Transects per site and depth are represented by codes (using one letter and one number) and symbols. Letters A, B and C represent sampling sites $\mathrm{A}, \mathrm{B}$ and $\mathrm{C}$, while the final digit correspond to the transect number. Symbols show the sampling depths: red circles are $6 \mathrm{~m}$, black crosses are $12 \mathrm{~m}$, and blue squares are $20 \mathrm{~m}$. 
deeper stations. Increased coverage of Pocillopora at shallower depths was associated with $C$. marginatus, $S$. rubroviolaceus, $Z$. cornutus, T. grammaticum and T. robertsoni. In contrast, Pavona cover correlated positively to the fish species $B$. diplotaenia and $K$. analogus, particularly in the transects of site B at 12 and $20 \mathrm{~m}$ depth, and with some species at $12 \mathrm{~m}$ depth at site $\mathrm{C}$ (Fig. 4).

\section{DISCUSSION}

The reef fish assemblage structure at Clipperton Atoll (characterized by species richness, diversity, biomass and species composition) varies as a function of LCC, through a depth gradient. However, the reef fish assemblage is characterized by low fish species richness and diversity, despite the large existing LCC.

Clipperton Atoll has a well-developed coral reef structure compared with other coral reefs in the ETP, which typically have shallow, irregular and limited coral reef formations (Veron 2015). The low reef fish species richness found at Clipperton Atoll is in accordance with patterns described for other oceanic islands of the ETP, such as the Cocos and Malpelo (Glynn et al. 1996), Galapagos (Glynn and Wellington 1983) and Revillagigedo (Castro-Aguirre and Balart 2002) islands. However, the reef fish species richness of the Clipperton Atoll is one of the lowest of the ETP coral reefs, though it is the largest coral reef, at 370 ha (Glynn et al. 1996, Salvat et al 2008). A total of 197 species are currently known for Clipperton Atoll, while a total of 76 have been seen in situ during several field samplings (Fourriére et al. 2014). Several authors have pointed to a bottom-up causal relationship between the reefscape and fish species, suggesting that a high LCC and high coral species richness can support more fish species at higher abundances (Chabanet et al. 1997, Arias-González et al. 2011, Acosta-González et al. 2013). The LCC at Clipperton Atoll is high, but with a low coral species richness (Glynn et al. 1996, Salvat et al. 1998), and this is likely to be reflected in the low fish species richness and diversity found. It is also necessary to consider that the low functional connectivity and geomorphology of Clipperton Atoll (i.e. no channels connect the inner lagoon with the reef and surrounding sea and there is no reef crest present) (Glynn et al. 1996) could also be promoting this low fish species richness.

The similarity in fish species richness and biomass among sites sampled at Clipperton Atoll was in accordance with results reported by Salvat et al. (2008), who described similar fish abundance in the northern and southern part of the atoll. The homogeneous geomorphology along the Clipperton Atoll, as well as its small size, could lead to similar fish species richness and biomass values among the sites, while the differences found in fish assemblage diversity and composition could be associated with the different growthforms among coral genera (i.e. massive, encrusting, columnar, laminar and branching corals), particularly at site A, where average cover of Porites was higher than at the other sites. This corresponds to the findings of Rodríguez-Zaragoza et al. (2011), who reported a strong relation of Porites cover with reef fish assemblages of the Mexican Pacific coral ecosystems. The species that most contributed to the composition of the fish assemblages studied among sites were classified by Robertson and Allen (1996) as residents in Clipperton Atoll, due to their high abundance and frequent observation. However, while these species are associated with tropical reefs, none are dependent on the coral for survival (Robertson and Allen 1996, Allen and Robertson 1997).

At Clipperton Atoll, the fish species richness, biomass and composition, as well as the cover of different coral genera, showed significant variation with increasing depth. In fact, higher coral cover, especially that of the genera Porites and Pavona, could be promoting the high biomass and species richness deeper stations. The most abundant fish species at 6 and $12 \mathrm{~m}$ belonged mainly to the families Acanthuridae, Pomacentridae and Labridae, and are commonly shallow-water species (Robertson and Allen 1996). Among them, the species S. baldwini and $T$. robertsoni stand out as endemic to Clipperton and are associated with coral reefs and rocky reefs (Robertson and Allen 2015). Broadly, the fish species A. nigricans, C. marginatus, A. triostegus and $T$. robertsoni are common below the surf zone or in areas affected by turbulent waves and strong currents (Dominici-Arosemena and Wolff 2006, Robertson and Allen 2015), and they are also associated with coral reefs and rocky reefs (Robertson and Allen 2015). The RDA developed in this study confirmed these relationships. In particular, A. nigricans and $A$. triostegus had a clear preference for a depth of $6 \mathrm{~m}$, while $C$. marginatus and $T$. robertsoni had an affinity for the coral genus Pocillopora. Dominici-Arosemena and Wolff (2006) also stated that A. nigricans prefer shallow rocky reefs with colonies of Pocillopora and exposure to strong waves. At $20 \mathrm{~m}$ depth, the low ecological diversity was likely to be the result of the greater dominance of species such as $D$. dermatolepis and M. berndti. Most of the fish species recorded at this depth are also associated with coral reefs and rocky reefs (Robertson and Allen 2015).

The small size and the low benthic substrate heterogeneity of Clipperton Atoll, due to the presence of fewer hermatypic coral species and morphofunctional groups of coral (Glynn 1996, Carricart-Ganivet and Reyes-Bonilla 1999), probably contributes to the low fish species richness observed. Nevertheless, we found several species-specific relations among coral reef fishes and hermatypic corals at particular depths. In conclusion, this study showed that the live cover of hermatypic corals is an important variable that modulates the structure of the reef fish assemblages at Clipperton Atoll and that depth also plays an important role. Despite the importance of LCC in shaping reef fish assemblage structure, higher coral species diversity seems to be necessary in order to increase fish species richness in coral reefs ecosystems with low habitat heterogeneity. 


\section{ACKNOWLEDGEMENTS}

This survey was conducted during the French Expedition Clipperton organized by Jean-Louis Etienne with the R/V Rara Avis, in collaboration with the École Pratique des Hautes Études, University of Perpignan, France. We thank staff members and colleagues for their help during field work. M. Adjeroud was supported by grants from World Wildlife Fund, France. This is a contribution of the LABEX Corail. Also, this work was a collaboration among the academic groups Recursos Marinos Tropicales (UADY-CA-95) of the Universidad Autónoma de Yucatán and Ecosistemas Marinos y Pesquerías (UDU-CA-46) and Investigaciones Costeras (UDG-CA-304) of the Universidad de Guadalajara.

\section{REFERENCES}

Acosta-González G., Rodríguez-Zaragoza F.A., Hernández-Landa R.C., et al. 2013. Additive Diversity Partitioning of Fish in a Caribbean Coral Reef Undergoing Shift Transition. Plos One 8: e65665 http://dx.doi.org/10.1371/journal.pone.0065665

Adjeroud M., Letourneur Y., Porcher M., et al. 1998. Factors influencing spatial distribution of fish communities on a fringing reef at Mauritius, SW Indian Ocean. Environ. Biol. Fish. 53: 169-182. http://dx.doi.org/10.1023/A:1007494920381

Aguilar-Medrano R., Calderón-Aguilera L.E. 2015. Redundancy and diversity of functional reef fish groups of the Mexican Eastern Pacific. Mar. Ecol. 37: 119-133. http://dx.doi.org/10.1111/maec.12253

Allen G.R. 2007. Conservation hotspots of biodiversity and endemism for Indo-Pacific coral reef fishes. Aquat. Conserv. 18: 541-556. http://dx.doi.org/10.1002/aqc.880

Allen G.R., Robertson D.R. 1997. An annotated checklist of the fishes of Clipperton Atoll, tropical eastern Pacific. Rev. Biol. Trop. 45: 813-843.

Alvarez-Filip L., Gill J.A., Dulvy N.K. 2011. Complex reef architecture supports more small-bodied fishes and longer food chains on Caribbean reefs. Ecosphere 2: 1-17. http://dx.doi.org/10.1890/ES11-00185.1

Anderson G.R.V., Ehrlich A.H., Ehrlich P.R., et al. 1981. The community structure of coral reef fishes. Am. Nat. 117: 476-495. http://dx.doi.org/10.1086/283729

Anderson M.J., Gorley R.N., Clarke K.R. 2008. PERMANOVA+ Primer: Guide to Software and Statistical Methods. PRIMER-E Ltd, Plymouth, UK, 214 pp.

Arias-González J.E., Done T.J., Page C.A., et al. 2006. Towards a reefscape ecology: relating biomass and trophic structure of fish assemblages to habitat at Davies Reef, Australia. Mar. Ecol. Prog. Ser. 320: 29-41. http://dx.doi.org/10.3354/meps320029

Arias-González J.E., Legendre P., Rodríguez-Zaragoza F.A. 2008. Scaling up beta diversity on Caribbean coral reefs. J. Exp. Mar. Biol. Ecol. 366: 28-36. http://dx.doi.org/10.1016/j.jembe.2008.07.035

Arias-González J.E., Nuñez-Lara E., Rodríguez-Zaragoza F.A., et al. 2011. Reefscape proxies for the conservation of Caribbean coral reef biodiversity. Cienc. Mar. 37: 87-96. http://dx.doi.org/10.7773/cm.v37i1.1746

Ault T.R., Johnson C.R. 1998. Spatial variation in fish species richness on coral reefs: habitat fragmentation and stochastic structuring processes. Oikos 82: 354-364 http://dx.doi.org/10.2307/3546976

Béarez P., Séret B. 2008. Les poissons de Clipperton. In: Charpy L. (ed), Clipperton: Environnement et Biodiversité d'un Microcosme Océanique. Patrimoines Naturels, Muséum National d'Histoire Naturelle and IRD Éditions, Paris, pp. 143-154.

Cáceres I., Ortiz M., Cupul-Magaña A.L., et al. 2015. Trophic models and short-term simulations for the coral reefs of Cayos Cochinos and Media Luna (Honduras): a comparative network analysis, ecosystem development, resilience, and fishery. Hyd- robiologia 770: 209-224

http://dx.doi.org/10.1007/s10750-015-2592-7

Carricart-Ganivet J.P., Reyes-Bonilla H. 1999. New and previous records of Scleractinian corals from Clipperton Atoll, Eastern Pacific. Pac. Sci. 53: 370-375.

Castro-Aguirre J.L., Balart E.F. 2002. La ictiofauna de las Islas Revillagigedo y sus relaciones zoogeográficas, con comentarios acerca de su origen y evolución. In: Lozano-Vilano M.L. (ed.), Libro jubilar en honor al Dr. Salvador Contreras Balderas. Universidad Autónoma de Nuevo León, México, pp. 153-170.

Clarke K.R., Gorley R.N. 2006. Primer v6: User Manual/Tutorial. PRIMER-E Ltd., Plymouth, UK, 192 pp.

Chabanet P., Ralambondrainy H., Amanieu M., et al. 1997. Relationships between coral reef substrata and fish. Coral Reefs 16: 93-102. http://dx.doi.org/10.1007/s003380050063

Chittaro P.M. 2004. Fish-habitat associations across multiple spatial scales. Coral Reefs 23: 235-244. http://dx.doi.org/10.1007/s00338-004-0376-z

Colwell R.K. 2013. EstimateS: statistical estimation of species richness and share species from samples. Version 9.1. Available on line at: http://viceroy.eeb.uconn.edu/estimates. University of Connecticut, Storrs, USA.

Dominici-Arosemena A., Wolff M. 2006. Reef fish community structure in the Tropical Eastern Pacific (Panamá): living in a relatively stable rocky reef environment. Helgol. Mar. Res. 60: 287-305. http://dx.doi.org/10.1007/s10152-006-0045-4

Fourriére M., Reyes-Bonilla H., Rodríguez-Zaragoza F.A., et al. 2014. Fishes of Clipperton atoll, Eastern Pacific: checklist, endemism and analysis of completeness of the inventory. Pac. Sci. 68: 375-395. http://dx.doi.org/10.2984/68.3.7

Froese R., Pauly D. 2015. FishBase. World Wide Web electronic publication. http://www.fishbase.org, version (02/2015).

Galzin R. 1987. Structure of fish communities of French Polynesian coral reefs. I. Spatial scales. Mar. Ecol. Prog. Ser. 41: 129-136. http://dx.doi.org/10.3354/meps041129

Glynn P.W., Wellington G.M. 1983. Corals and Coral Reefs of the Galápagos Islands (with an Annotated List of the Scleractinian Corals of Galápagos by J.W. Wells). University of California Press, Berkeley, California, 330 pp.

Glynn P.W., Veron J.E.N., Wellington G.M. 1996. Clipperton Atoll (Eastern Pacific): oceanography, geomorphology, reef-building coral ecology and biogeography. Coral Reefs 15: 71-99. http://dx.doi.org/10.1007/BF01771897

Iglesias-Prieto R., Beltrán V.H., LaJeunesse T.C., et al. 2004. Different algal symbionts explain the vertical distribution of dominant reef corals in the eastern Pacific. Proc. Biol. Sci. 271: 1757-1763. http://dx.doi.org/10.1098/rspb.2004.2757

Jackson J.B.C., Kirby M.X., Berger W.H., et al. 2001. Historical overfishing and the recent collapse of coastal ecosystems. Science 293: 629-638. http://dx.doi.org/10.1126/science.1059199

Legendre P., Gallagher E.D. 2001. Ecologically meaningful transformations for ordination of species data. Oecologia 129: 271-280 http://dx.doi.org/10.1007/s004420100716

Mellin C., Andréfouët S., Kulbicki M., et al. 2008. Remote sensing and fish-habitat relationships in coral reef ecosystems: Review and pathways for systematic multi-scale hierarchical research. Mar. Pollut. Bull. 58: 11-19. http://dx.doi.org/10.1016/j.marpolbul.2008.10.010

Méndez E., Ruiz L.J., Prieto A., et al. 2006. Fish community of a fringing reef at Mochima National Park, Venezuela. Cienc. Mar. 32: 683-693.

Ohman M.C., Rajasuriya A. 1998. Relationship between habitat structure and fish communities on coral and sandstone reefs. Environ. Biol. Fishes 53: 19-31. http://dx.doi.org/10.1023/A:1007445226928

Roberts C.M., Ormond R.F. 1987. Habitat complexity and coral reef diversity and abundance on Red Sea fringing reefs. Mar. Ecol. Progr. Ser. 41: 1-8 http://dx.doi.org/10.3354/meps041001

Robertson D.R., Allen G.R. 1996. Zoogeography of the shorefish fauna of Clipperton Atoll. Coral Reefs 15: 121-131. http://dx.doi.org/10.1007/BF01771902

Robertson D.R., Allen G.R. 2015. Shorefishes of the Tropical Eastern Pacific online information system. Version 2.0 Smithsonian 
Tropical Research Institute, Balboa, Panamá. http://biogeodb. stri.si.edu/sftep/es/pages.

Rodríguez-Zaragoza F.A., Arias-González J.E. 2015. Coral biodiversity and bio-construction in the northern sector of the mesoamerican reef system. Front. Mar. Sci. 2: (13): 1-3. http://dx.doi.org/10.3389/fmars.2015.00013

Rodríguez-Zaragoza F.A., Cupul-Magaña A.L., Galván-Villa C.M., et al. 2011. Additive partitioning of reef fish diversity variation a promising marine biodiversity management tool. Biodivers. Conserv. 20: 1655-1675 http://dx.doi.org/10.1007/s10531-011-0053-9

Sale P.F. 1991. Introduction. In: Sale P.F. (ed.), The ecology of fishes on coral reefs. Academic Press, California USA, pp 3-15. http://dx.doi.org/10.1016/B978-0-08-092551-6.50006-4

Salvat B., Adjeroud M., Charpy L. 2008. Les récifs coralliens de Clipperton. Rev. Ecol. Terre Vie. 63: 179-187.

ter Braak C.J.F., Šmilauer P. 2002. CANOCO Reference Manual and CanoDraw for Windows User's Guide: Software for Canonical Community Ordination (version 4.5). Microcomputer Power, Ithaca NY, USA, $500 \mathrm{pp}$.

Veron J., Stafford-Smith M., DeVantier L., et al. 2015. Overview of distribution patterns of zooxanthellate Scleractinia. Front. Mar. Sci. 1: 81

http://dx.doi.org/10.3389/fmars.2014.00081

\section{SUPPLEMENTARY MATERIAL}

The following material is available through the online version of this article and at the following link:

http://scimar.icm.csic.es/scimar/supplm/sm04301esm.pdf

Fig. S1. - Evaluation of sampling effort and species richness for fish at the Clipperton Atoll. A, number of observed and estimated species using Chao 1, Chao 2, and Jackknife 2; B, Shannon diversity $\left(\mathrm{H}^{\prime}\right)$ accumulation curve; rarefaction curves by site $(\mathrm{C})$ and depth (D).

Table S1. - Reef fish species composition, abundance and rarity at Clipperton Atoll.

Table S2. - Results of two-way similarity percentage analysis (SIMPER) of reef fish species biomass found at each site at the Clipperton Atoll.

Table S3. - Results of two-way similarity percentage analysis (SIMPER) of reef fish species biomass found at each depth on the Clipperton Atoll. 


\section{Coral reef fish assemblages at Clipperton Atoll (Eastern Tropical Pacific) and their relationship with coral cover}

Aurora M. Ricart, Fabián A. Rodríguez-Zaragoza, Carlos González-Salas, Marco Ortiz, Amílcar L. Cupul-Magaña, Mehdi Adjeroud

Supplementary material 

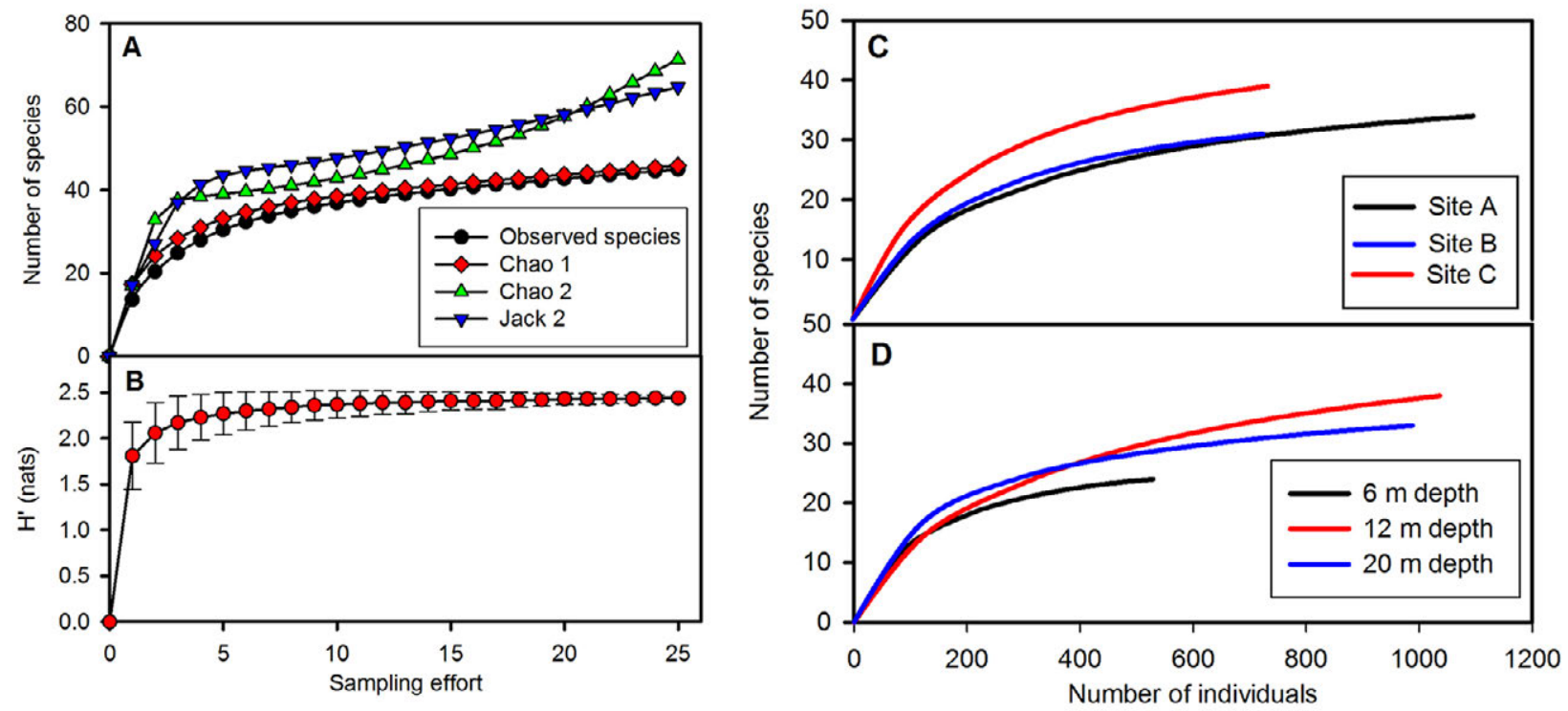

Fig. S1. - Evaluation of sampling effort and species richness for fish at the Clipperton Atoll. A, number of observed and estimated species using Chao 1, Chao 2, and Jackknife 2; B, Shannon diversity $\left(\mathrm{H}^{\prime}\right)$ accumulation curve; rarefaction curves by site (C) and depth (D).

Table S1. - Reef fish species composition, abundance and rarity at Clipperton Atoll.

\begin{tabular}{|c|c|c|c|c|c|c|c|}
\hline \multirow[b]{2}{*}{ Family } & \multirow[b]{2}{*}{ Species } & \multirow{2}{*}{$\begin{array}{l}\text { Average biomass } \\
\quad\left(\mathrm{g} \mathrm{m}^{-2}\right)\end{array}$} & \multirow{2}{*}{$\begin{array}{l}\text { Total density } \\
\left(\text { ind } / 1250 \mathrm{~m}^{2} \text { ) }\right.\end{array}$} & \multicolumn{4}{|c|}{ Species rarity } \\
\hline & & & & Singletons & Doubletons & $\begin{array}{l}\text { Unique } \\
\text { species }\end{array}$ & $\begin{array}{c}\text { Duplicate } \\
\text { species }\end{array}$ \\
\hline Serranidae & Dermatolepis dermatolepis & 59.11 & 51 & & & & \\
\hline Holocentridae & Myripristis berndti & 46.09 & 126 & & & & \\
\hline Acanthuridae & Ctenochaetus marginatus & 45.03 & 217 & & & & \\
\hline Carangidae & Caranx lugubris & 37.07 & 57 & & & & \\
\hline Serranidae & Epinephelus labriformis & 19.44 & 30 & & & & \\
\hline Acanthuridae & Acanthurus nigricans & 19.24 & 132 & & & & \\
\hline Kyphosidae & Kyphosus elegans & 17.91 & 35 & & & & \\
\hline Carangidae & Caranx melampygus & 15.65 & 28 & & & & \\
\hline Scaridae & Scarus rubroviolaceus & 14.41 & 22 & & & & \\
\hline Serranidae & Paranthias colonus & 11.85 & 120 & & & & \\
\hline Aulostomidae & Aulostomus chinensis & 10.80 & 13 & & & & \\
\hline Balistidae & Sufflamen verres & 9.34 & 17 & & & & \\
\hline Labridae & Bodianus diplotaenia & 7.02 & 16 & & & & \\
\hline Balistidae & Melichthys niger & 5.24 & 21 & & & & \\
\hline Kyphosidae & Kyphosus analogus & 5.02 & 11 & & & & \\
\hline Carangidae & Caranx sexfasciatus & 3.70 & 6 & & & & \\
\hline Kyphosidae & Sectator ocyurus & 3.48 & 2 & & $X$ & $X$ & \\
\hline Muraenidae & Enchelycore octaviana & 3.42 & 12 & & & & \\
\hline Mullidae & Mulloidichthys dentatus & 3.06 & 34 & & & & \\
\hline Acanthuridae & Acanthurus triostegus & 2.90 & 30 & & & & \\
\hline Pomacanthidae & Holacanthus limbaughi & 2.53 & 21 & & & & \\
\hline Cirrhitidae & Cirrhitus rivulatus & 2.14 & 4 & & & & \\
\hline Zanclidae & Zanclus cornutus & 1.95 & 27 & & & & \\
\hline Lutjanidae & Lutjanus viridis & 1.84 & 16 & & & & \\
\hline Labridae & Thalassoma grammaticum & 1.54 & 105 & & & & \\
\hline Ostraciidae & Ostracion meleagris & 0.78 & 9 & & & & \\
\hline Pomacentridae & Stegastes baldwini & 0.77 & 232 & & & & \\
\hline Labridae & Thalassoma robertsoni & 0.73 & 1042 & & & & \\
\hline Tetraodontidae & Arothron meleagris & 0.70 & 10 & & & & \\
\hline Muraenidae & Gymnothorax flavimarginatus & 0.58 & 2 & & $\mathrm{X}$ & & $\mathrm{X}$ \\
\hline Muraenidae & Gymnothorax dovii & 0.58 & 2 & & $X$ & $X$ & \\
\hline Holocentridae & Sargocentron suborbitalis & 0.45 & 4 & & & $\mathrm{X}$ & \\
\hline Bothidae & Bothus mancus & 0.44 & 1 & $\mathrm{X}$ & & $\mathrm{X}$ & \\
\hline Labridae & Thalassoma purpureum & 0.43 & 1 & $\mathrm{X}$ & & $\mathrm{X}$ & \\
\hline Labridae & Novaculichthys taeniourus & 0.40 & 1 & $\mathrm{X}$ & & $\mathrm{X}$ & \\
\hline Chaetodontidae & Johnrandallia nigrirostris & 0.25 & 29 & & & & \\
\hline Labridae & Xyrichtys wellingtoni & 0.17 & 1 & $\mathrm{X}$ & & $\mathrm{X}$ & \\
\hline Acanthuridae & Acanthurus xanthopterus & 0.16 & 2 & & $X$ & $\mathrm{X}$ & \\
\hline Acanthuridae & Acanthurus achilles & 0.13 & 2 & & $X$ & $\mathrm{X}$ & \\
\hline Blenniidae & Ophioblennius steindachneri & 0.08 & 7 & & & & \\
\hline Chaetodontidae & Forcipiger flavissimus & 0.08 & 18 & & & & \\
\hline Cirrhitidae & Cirrhitichthys oxycephalus & 0.04 & 19 & & & & \\
\hline Tetraodontidae & Canthigaster punctatissima & 0.023 & 4 & & & & \\
\hline Gobiidae & Bathygobius arundelii & 0.010 & 2 & & $X$ & $X$ & \\
\hline Labridae & Thalassoma virens & 0.002 & 12 & & & $\mathrm{X}$ & \\
\hline
\end{tabular}




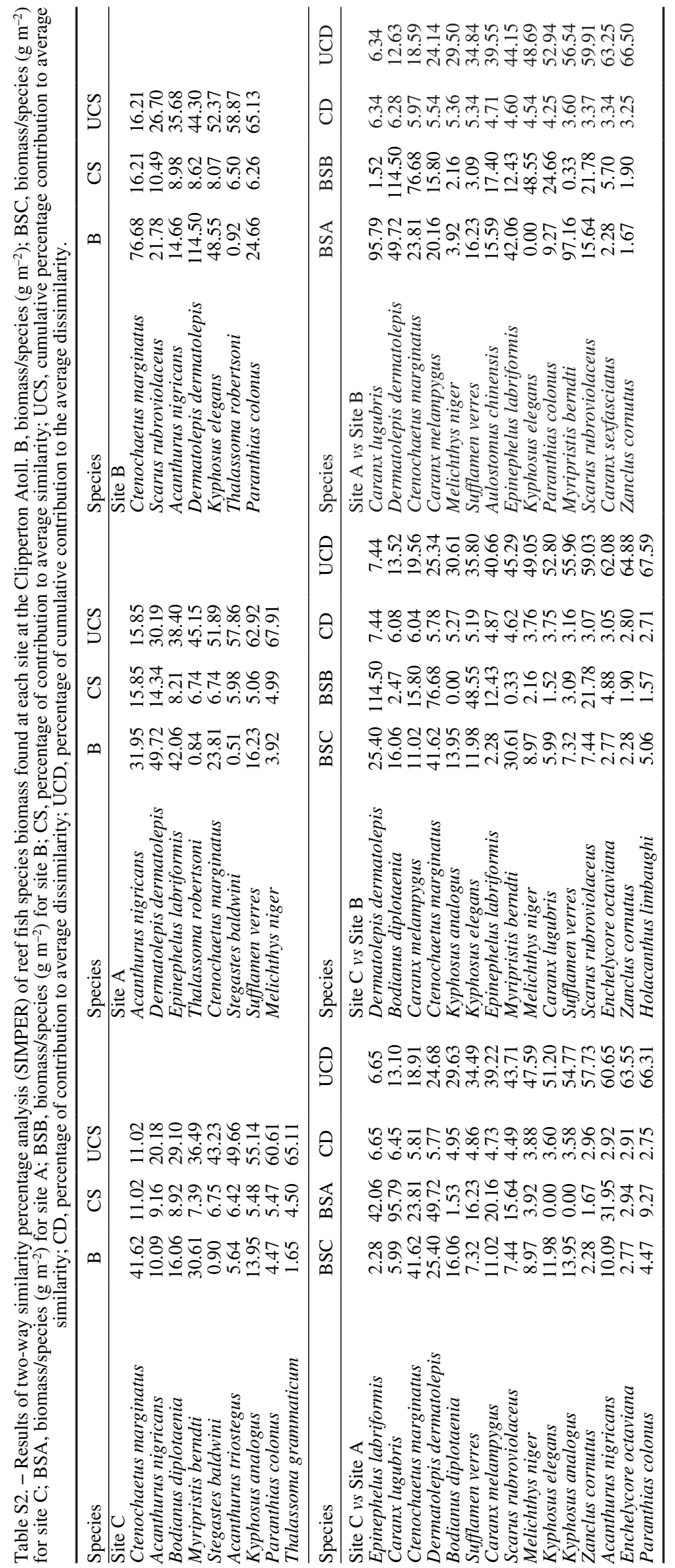




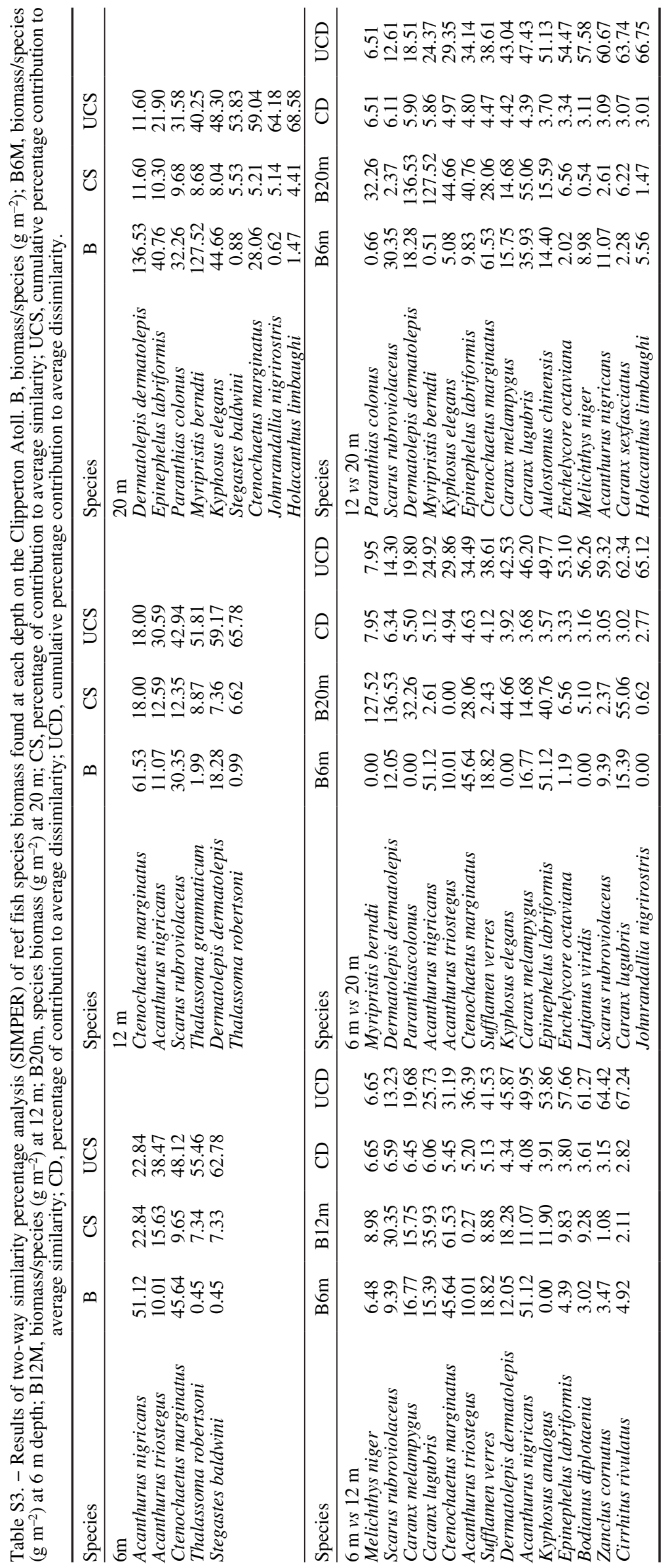

